\title{
Mythology in folklore and its features
}

\author{
Hikmatova Muqadas Nurilloevna, \\ Associate professor, \\ Candidate of philological sciences, head of \\ ESP for Humanitarian Subjects, \\ Bukhara State University
}

Abstract - in the article, folk art - artistic, creative-practical and amateur activity of the masses; folklore, folk music (folklore), folk theater (performing arts), folk dances (dances), puppetry, wood and wooden foot games (folk circus), folk fine and applied arts of traditional material and intangible culture information and examples of art and technical and artistic hobbies.

Key words: folklore, folk music, folk theater, folk dances, folk circus, mythological concepts.

\section{Introduction}

The types of folk art that are involved in the creation and creative process are formed in accordance with the people's way of life, living conditions, level of social work, passed from generation to generation, from teacher to student, are constantly improved, polished, become more traditional and finally professional. , live performance conditions and has reached us in daily practice. There are also a number of works of folk art. Samples have been preserved in written sources, in the works of historians and writers, in rocks (such as Sarmishsay, Zarautsoy paintings), in archeological and architectural monuments, and in artefacts. Examples of folk art reflect the people's way of life, social and domestic life, labor, nature and society, beliefs and religious beliefs, feelings about man and the world, the world of art, education, happiness and justice.

\section{2. .Literature review}

Folk art has developed since ancient times. With the development of society and the strengthening of the division of labor, the specialization of some talented people in the genres of folk art increased. Thus, bakhshis, clowns, amateurs, puppet masters, dancers, painters, potters, sculptors, embroiderers, etc. art emerged, entrepreneurs and bosses emerged. However, the participation of the masses in its creation and assimilation has been maintained, and every performance or practice has taken place within the framework of a long-established tradition. All creative behavior, innovation took place within the framework of stable traditions and teacher-student relations. On the one hand, the traditions themselves developed, on the other hand, changes, innovations, new works and variants appeared during each performance or practice. Some have been forgotten, dropped from execution and practice.

Folklore helps each artist to find their own way, style, identity, root. "Literature begins with a myth and ends with a myth," says Jorge Luis Borges, one of Latin America's greatest writers. In other words, any art, including the art of rhetoric, begins with folklore and develops along with folklore. Folklore and history are a really topical issue. After all, epics, which are examples of oral creation, are not just works of art, but also a national encyclopedia that embodies the history, culture, customs and traditions of the people, the way of thinking.

\section{Analysis}

Consider only the epic Alpomish. This epic has a special place not only in Uzbek, but also in world epics, it is an example of epic creation with ancient historical roots and high artistic value. This story has been studied a lot. However, the role of this friend in world folklore, its mythological foundations and artistic layers still need to be studied again and again.

Let's look at the first sentence in the beginning of the story. Epic begins as: «Burungi o'tgan zamonda, o" $n$ olti urug' Qo'ng'irot elida Dobonbiy degan o'tdi. Dobonbiydan Alpinbiy degan o'g'il farzand paydo bo'ldi. Alpinbiydan tag'i ikki o'g'il paydo bo'ldi: kattakonining otini Boybo'ri qo'ydi, kichkinasining otini Boysari qo'ydi. Boybo'ri bilan Boysari - ikkovi katta bo'ldi. Boysari boy edi, Boybo'ri esa shoy edi, bul ikkovi ham farzandsiz bo'ldi»("In the past, sixteen tribes were called Dobonbiy in Kungrad. Dobonbiy gave birth to a son, Alpinbi. Alpinbi had two more sons: the eldest was named Boybori and the youngest was named Boysari. Boybori and Boysari - both grew up. Boysari was rich and Boybori was king, and they both lost their children).

According to the mythological concept, the " Burungi o"tgan zamon (past)" is the beginning of the beginning, the transformation of chaos into space. For Srun, our tales begin, "Bir bor ekan, bir yo'q ekan, burun o'tgan zamonda (Once upon a time, once upon a time, in the past)." As you say, this is a numberless, pure, artistic history of any nation. We are not talking about unreal, artistic fabric that has no basis in life. Maybe it's half a myth, half a truth, a mythological past, a history. Unlike a fairy tale, both the narrator and the listener believe that the story is true. In addition, the epic is about the sacred memory of the ancestors, the glorious history. These glorious events continue to be sung, passed down, and performed by generations.

"O'n olti urug' Qo'ng'irot eli(Sixteen generations of the Kungrad People" gives more vividness to the above history. This history emphasizes that a particular tribe is at the same time connected with the past of the whole nation. 
The word "Dobonbiy" means a pass, a height. This name is simply not selected. It is a symbolic image of a hero who has done great things in life, achieved great things. In the epic, these lines seem to be imperfect, a name that is remembered at the beginning of the epic and then forgotten. However, the next sentences, the next events will clarify this image. Like Alpinbey, the birth of the Alps did not happen by itself. It was because of Dobonbi's hard work and wisdom.

The prefix "Boy" in the names Boybori and Boysari indicates who their family tree is. Note, however, that Dobonbiy and Alpinbiy are listed, followed by two pairs of names. Is this nonsense?

In folklore, there is the concept of twins. Both names are somewhat artistic interpretations of the concept of twins. Usually in the mythological notion of twins, one of the twins is big and the other is small. Perceptions of maternal fertility In the period when the predominant law was being discovered, the emphasis was more on the younger, and in many cases directly on the mother. Fairy tales such as "The Little Brave", "The Third Son" and the epics "Alibek and Bolibek" are vivid examples of this.

Only here the emphasis is not on Boysari, but on Boybori. It is no coincidence that Alpomish is also the son of Boybori. So it is arguable that intoxicants of choice runs the taste in folklore. However, other interpretations of the epic, including the images of Barchin, Qaldirgoch, the old woman Surkhayil, and Tovka, show that the notion of maternal ancestry in the epic is still stable.

The childlessness of the parents before the birth of the Alpine hero is in fact symbolic, it is about the birth of a new generation - the Alps, which will strengthen the kingdom and reunite the scattered people.

In the epic "Alpomish" the division and disintegration of the nation is expressed through the migration of Boysari to the Kalmyk people. The Turkic peoples have had great kingdoms, power and unlimited domination in certain periods of history. This great kingdom has been destroyed due to divisions, wars and other reasons. Then a new generation, the Alps, was born, which was able to unite the people and the nation, and the former high position of the Turkic peoples on the stage of history was regained. The artistic expression of the same events is the essence of "Alpomish".

It should be noted that in "Alpomish" only Hakimbek can shoot a rusty bow left by Alpinbi in the lake. The rusting of the alpine bow on the lake indicates that the previous generation was not able to complete its mission. Only a new generation - the Alps - will complete such a task.

\section{Discussion}

There are different approaches to the alpine system in epic creation. Foreign scholars Lord Raglen, Karl Reichl, and Ojal Oghuz use the term "heroic pattern" in their research, while Uzbek folklorists use the term "alpine system." That is, a hero in folklore is not just a hero, but there are aspects that emphasize his courage, bravery and heroism. These aspects come in the form of epic patterns in epics. I.e. heroes follow a certain system. There are many more such examples.

From the very first sentence of the epic, the notions of the glorious past of our ancestors are firmly rooted. So, this situation brings some clarity to the mythological layer of the epic, as well as to the period of its emergence. In other words, it gives a very rich and valuable information about the thousands of years of history and way of thinking of the people.

In the examples of folklore, a very exaggerated depiction of reality can be seen as a contradiction to the reality of life in relation to the heroes. The epic "Alpomish" is no less eloquent than other epics. But if we look at the social relations in the work, we can see how close the reality of the work is to ordinary life. We see this feature in the conflicts that provide the dynamic development of the plot. Let's take the first conflict of the work: Boybori and Boysari go to the wedding. They are not honored at the wedding. The reason is that they do not have children, and the people do not believe that they will return this honor and blessings by having a wedding. This is the first conflict in the play and is the starting point of all the reality in the plot. The attitude towards Boybori and Boysaribi at the wedding is not artificial, but rather a natural phenomenon that is often seen in people's attitudes.

Let's take a look at the next event that will be the knot for the whole plot of the story. The incident of asking for zakat and the conflict in it are also described in a very natural way. Let's remember the story of Boybori thinking about the need to pay zakat and saying, "Let my brother not be a sinner." At a glance, we see a man who, out of the three qualities of a generous man, is inspired by Hakimbek's statement about zakat, which is only concerned with the world of wealth. If we think about it, we can feel the first step of the emerging government in reminding the debtors of their rights. This, in addition to recalling the laws of statehood, also reflects the real contradiction (the relationship of the strong with the weak) in social relations. The epic does not mention the relationship between Boybori and Boysari, their disagreement, ignorance, kindness and the reasons for this situation. However, the accompanying images in the work indirectly serve to draw this conclusion.

For example, Boybori's threat to the Barchin runners shows the absolute indifference of the ruler's brother to the fate of his comrades, his brother-in-law and the future bride: If you say to a woodcutter, or to a herdsman, or to a shepherd in the desert, "We would be Barchin's runner," a man will chase after you, whip you on the head, and tear your body to shreds, throws him to the gallows ... This expression is given with a very beautiful image. The power of artistic 
expression was used very wisely in the epic to make the most vivid and vivid portrayal of a difficult day that could befall the runners if the ban was violated.

In the epic Alpomish, the concept of man is very well defined. In the play, depending on the life situation and the personality of the protagonist, each image is approached differently, they are not overburdened. Particularly noteworthy in this respect are the heartfelt depictions of the Kalmyks squeezing the bells, the grievances of the runners who tried to report to Barchin that they were threatening them, and the greatness of their devotion to their horses and the insignificance of the result they achieved. At this point in the epic, the difference between man and man is vividly portrayed. With so much effort, effort, and effort, the runners barely reach Boysun in 90 days. In spite of the devotion, sincerity and earnestness of an ordinary person, the result of his activity is in itself - in its simplicity. Emergency work can only be done by an extraordinary person. That's why a person with extraordinary features is comfortable, sometimes even shaky. Because he believes that others can solve a thousand attempts with a single stroke. Self-confidence has created a feeling of heaviness and contentment in such a person. These aspects are taken into account in the epic.

While classifying the myths found in the Beowulf and Alpomish epics, they can be divided into threedimensional models of the universe based on ancient mythological motifs and images.

These are the images that embody the three-story universe model:

-Tangri(God);

-Yer-suv(Earth-water);

-O't-suv(Fire and water);

-Tog '(mountain);

- O'rmon(Forest) cults.

These images also have a mythological meaning because they are cults, and they played an important role in the formation of these two works as written literature. These cult-like images in the epics formed the basis of cosmogonic and ethnogenic myths. That is the purpose of the myth. In essence, a myth is a symbolic representation of the various elements of the structure of the universe and the form of the universe. In Alpomish, for example, the name of the world is very detailed about how the universe is shaped. There are various phenomena and different views on the creation of divine powers, such as the sun, moon, and stars, in the heavens and the universe.

\section{Conclusion}

Based on the above, mythological images in ancient folk tales and epics are depicted as symbols of Darkness, Cold, Sickness and Death or Light, Warmth, Health and Eternal Life. forms:

- Mythological evil forces act as characters in a fairy tale, which is the basis of endless contradictions in two

a) evil forces in the form of mythology - as dragons, demons, demons, etc.;

b) anthropological images - fairies, old women, etc.

- Beovulf depicts a terrible creature as a mythological image. This negative myth is created in opposition to Beowulf, a positive image, and one of the main motives of mythology is the victory of positive images against evil, which forms the basis of the epic.

\section{References:}

1. Secondary schools' didactic principles of teaching fine art. G.R. Ostonova

2. ACADEMICIA: An International Multidisciplinary Research Journal $10 \quad(7)$, 554-560 https://www.indianjournals.com/ijor.aspx?target=ijor:aca\&volume $=10 \&$ issue $=7 \&$ article $=080$

3. Psychological and pedagogical theoretical foundations of perception and imagination of fine arts by G.R. Ostonov's students European research: innovation in science, education and technology, 30-31 https://www.elibrary.ru/item.asp?id=411877163.

4. THE PROBLEM OF DEVELOPING STUDENTS'PERCEPTIONS OF VISUAL ARTS IN UZBEKISTAN O. G Razzoqovna European Journal of Research and Reflection in Educational Sciences Vol 7 (12)

5. http://www.idpublications.org/wp-content/uploads/2019/11/Full-Paper-

6. F.R. Muradova, S.M. Kadyrova The use of innovative methods in education.

7. Problems and prospects for the development of education, 62-63 pages, 2019 F.R. Muradova, R. J. Kadirov BULLETIN OF MASTER'S, 60 pages, 2019

8. F.R. Muradova, Game Technology for Science Lessons; Eastern European Scientific Journal, 2017 y. ,Pp. 107 109

9. Z.R.Murodova The formation and definition of the intellectual potential in education. ISJ Theoretical \& Applied science. Philadelphia, USA. 2020. Pp. 113-116.

10. F.R.Muradova Virtual laboratories in teaching and education. ISJ Theoretical \& Applied science. Philadelphia, USA. 2020. Pp. 106-109. 
11. Muradova F.R., Murodova Z.R. Use of information technologies in education/International Journal of Psychosocial Rehabilitation, UK. -2020.- Pp. 3110-3116

12. Rajabova M.B. Goethe and the East. International scientific-practical conference "XL international conference dedicated to the problems of social sciences" (March 31, 2016) Moscow -2016. Pp.43-38.

13. Amonova Zilola Kadirovna, Sharipova Mekhriniso Shavkatovna. " The Reflection of Nasimi`S Concepts in The Works of Atoi". International Journal of Psychological Rehabilitation. (Indexed by Scopus) ISSN: 1475-7192. Volume 24- Issue 9. June 2020. 3669-3676 p.

14. Sharipova Mekhriniso Shavkatovna. "Philosophical analysis of the hero of Amir Temur" "International Journal on Integrated Education" Scientific Journal Impact Factor. (Impact factor 5.083) e-ISSN:26203502 p-ISSN : 26153785 Indonesia, Volume 3, Issue III, March 2020, 87-89 p.

15. Marifat Bakaevna Razhabova. From the history of the views of the great thinkers of the East on education and upbringing. International scientific and practical conference "Fundamental and applied research: a new word in science", Moscow, December 15, 2014. pp. 125-132.

16. Rajabova Marifat Bakaevna. Artistic interpretation of the mythonyms of angel and devil in the works of A.Navoi. Middle European Scientific Bulletin, ISSN 2694-9970 .VOLUME 5, OCTOBER 2020. Pp. 135-131.

17. Bukhara Taj Mahal (Char Minar) Sh.B. Avliyakulova, G.R. Ostonova Young Scientist, 956-959 https://www.elibrary.ru/item.asp?id=26423371

18. In the Fine Arts of Uzbekistan, the ancient method of Abru-Bakhor

19. G.R. Ostonova Eurasian Scientific Journal, 468-473

20. https://www.researchgate.net/profile/Begmullayev_Otabek/publication/340514893_Evrazijskij_zurnal/links/5e8 e286992851c2f5288e2c9/Evrazijskij-zurnal.pdf\#page $=468$

21. The essence of the creative process in man and his psychology G.R. Ostonova EURASIAN SCIENCE, 59 http://77.246.158.243/upload/uf/527/527e82895a9a11a5285df0d5793887cd.pdf\#page=59

22. Miniature art of the Timurid period G.R. Ostonova International scientific journal, 34-35 file: /// D: $1 \%$ D0\% 97\% D0\% B0\% D0\% B3\% D1\% 80\% D1\% 83\% D0\% B7\% D0\% BA\% D0\% B8 / mnj_2016_8_10 \% 20 (1) .pdf

23. A new method of Abru-Bakhor technique in the art of book illustration by G.R. Ostonova Young scientist, 1619-1623 https://www.elibrary.ru/item.asp?id=26425220

24. Portraits of Amir Timur and Zakhiriddin Mukhamed Babur in the works of the People's Artist of Uzbekistan Malik Nabiev G.R. Ostonova Young scientist, 1617-1619 https://www.elibrary.ru/item.asp?id=26425219

25. Articles in the Academy NATURAL DYES IN COLORING SILK THREADS AND PRODUCTS G.R. Ostonova, S.P.Sattorova [DOC] from the site esrae.ru

26. Akhnedova M.B. Genetic and Structural Specifications of the Spirituality Nominative Units in the Uzbek Language. Theoretical and Applied Science Journal, 10 (86), 2018.- P.331-333

27. Avdiyev V. I. History of the Ancient East. - Tashkent: Uzbekistan. 1964.841-p.

28. Afzalov M.I. About Uzbek folk tales. Tashkent "Fan" 1964.120-p. 